\title{
Kemampuan Pemecahan Masalah dan Kreativitas Peserta Didik dengan Pendekatan Berpikir Kausalitik Berscaffolding
}

\author{
Faisal, Joni Rokhmat*, Jannatin Ardhuha \\ Program Studi Pendidikan Fisika, Universitas Mataram \\ *Email: joni.fkip@unram.ac.id
}

Received: 31 Maret 2020;

Accepted: 19 April 2020;

Published: 24 April 2020

DOI: http://dx.doi.org/10.29303/jpft.v6i1.1771

\begin{abstract}
This research aimed to investigate problem-solving ability (PSA) and creativity of students through physics learning with causalitic-thinking approach with scaffolding of type $2 b$. With the scaffolding, in learning, students have to determine all causes and predict all possible effects in a phenomenon, also give arguments how conditions of each cause so that each effect occur. However, the number of the causes and effects is informed and part of the causes, effects, and arguments also be given so the students only need to complete them. This research used method of experiment with control group design. As population were students of class XI MIA SMAN 3 Mataram year 2017/2018 while as sample were the students of class XI MIA 8 and XI MIA 9. Data of the PSA and creativity were taken by using one set of test instrument and respectively analyzed with $t$-test and $U$-test at significance level of $5 \%$. The former test showed that $t_{\text {counted }}$ is 12.621 with $t_{\text {table }}$ of 2.004 which meant that the approach affected PSA of students. While, the latter one showed that $z_{\text {counted }}$ is 6.69 with ztable of 1.96 which meant that the approach also affected creativity of students.
\end{abstract}

Keywords: problem-solving; creativity; causalitic-tinking; approach; physics learning.

PENDAHULUAN

Setiap manusia menginginkan cita-cita dan impiannya tercapai. Cita-cita dan impian tersebut dapat tercapai apabila manusia tersebut memiliki bekal ilmu dan keahlian yang cukup. Banyak cara yang dapat digunakan untuk mencari ilmu dan keahlian tersebut. Salah satunya melalui pendidikan formal. Pendidikan merupakan sarana bagi seseorang untuk mencari pengetahuan serta kemampuan yang akan digunakan sebagai bakal menjalani kehidupanya. Tidak semua orang yang berhasil dan sukses memiliki latar belakang pendidikan formal yang baik. Namun kebanyakan dari orang yang berhasil dan sukses meraih kesuksesanya melalui jalur pendidikan formal. Semakin tinggi tingkat kehidupan yang ingin diraih seseorang, semakin banyak dan berat pula masalah yang akan dihadapinya. Oleh sebab itu, pendidikan awal yang diterima oleh para peserta didik haruslah dapat mengembangkan kemampuan pemecahan masalah mereka.
Menurut Tamami et al. (2017) kemampuan pemecahan masalah merupakan kemampuan dasar yang harus dimiliki oleh peserta didik untuk memecahkan setiap permasalahan dari guru. Kemampuan pemecahan masalah ini sangat diperlukan pada semua mata pembelajaran di sekolah terutama pembelajaran fisika. Berbagai permasalahan yang menyangkut fenomenafenomena alam dalam pembelajaran fisika memerlukan kemampuan pemecahan masalah yang baik agar mampu memecahkannya.

Besarnya keharusan memiliki kemampuan pemecahan masalah semakin meningkat seiring dengan kemajuan jaman. Terutama dengan berlakunya Kurikulum 2013 yang menuntut para peserta didik untuk aktif serta pembelajaran harus berpusat pada peserta didik itu sendiri dan bukan pada guru. Seorang guru tidak lagi menjadi satu-satunya sumber belajar bagi para peserta didik. Seorang guru dituntut agar lebih menjalankan perannya sebagai fasilitator 
yang menyediakan berbagai fasilitas untuk peserta didik dalam proses pembelajaran. Fasilitas ini termasuk menyediakan berbagai permasalahan yang harus dipecahkan oleh para peserta didik sehingga berbagai kemampuan dari peserta didik seperti kemampuan pemecahan masalah dapat berkembang dengan baik.

Selain dari kemampuan pemecahan masalah, kemampuan yang tidak kalah pentingnya bagi peserta didik adalah kreativitas. Menurut Hakim et al. (2017) berpikir secara kreatif sangatlah penting untuk dikembangkan dalam proses pembelajaran. Berbagai permasalahan dalam kehidupan memerlukan banyak solusi untuk menyelesaikannya. Agar dapat menemukan solusi-solusi tersebut, seseorang harus mampu berfikir secara kreatif. Deta et al. (2013) juga berpendapat bahwa peserta didik yang memiliki kreativitas tinggi akan memiliki kemampuan lebih baik saat berusaha menyelesaikan berbagai permasalahan-permasalahan terutama permasalahan yang berkaitan dengan aplikasi dari pelajaran yang ia pelajari. Berdasarkan teori pendukung tersebut, dapat disimpulkan bahwa kreativitas sangat dibutuhkan oleh peserta didik. Peserta didik yang berpikir secara kreatif akan memiliki kemampuan lebih baik saat berusaha menyelesaikan berbagai permasalahanpermasalahan sehingga kemampuan pemecahan masalah yang ia miliki dapat lebih berkembang.

Kemampuan pemecahan masalah dan kreativitas merupakan dua hal penting yang dapat dikembangkan melalui pendidikan formal. Bertujuan memperoleh gambaran pengembangan kemampuan pemecahan masalah dan kreativitas melalui pendidikan formal ini, wawancara dilakukan dengan guru fisika dan beberapa peserta didik di kelas XI di SMAN 3 Mataram. Berdasarkan hasil wawancara dengan guru fisika, ternyata guru seringkali menggunakan soal fisika dalam bentuk soal hitungan untuk mengevaluasi para peserta didik. Akibatnya peserta didik yang memiliki dasar matematika lemah mangalami kesulitan saat mengerjakan soal ini. Mereka sering kali tidak mampu menyelesaikan persamaan aljabar saat mengerjakan soal fisika. Hal ini didukung dengan hasil wawancara terhadap peserta didik sendiri. Berdasarkan hasil tersebut, beberapa kesulitan saat belajar fisika adalah menentukan persamaan yang digunakan untuk mengerjakan soal dan melakukan perhitungan matematika dari soal fisika tersebut.

Menurut Helmi et al. (2017), bentuk tes tulis fisika yang hanya mengandalkan persamaan fisika akan menghambat perkembangan kemampuan pemecahan masalah peserta didik. Kemampuan pemecahan masalah dan kreativitas seharusnya menjadi kemampuan yang sangat perlu dikembangkan di sekolah. Kemampuan pemecahan masalah dan kreativitas sendiri dapat dikembangkan dengan cara belajar yang tepat. Belum diterapkanya cara belajar yang dapat mengembangkan kemampuan pemecahan masalah dan kreativitas merupakan salah satu permasalahan yang harus diperhatikan oleh para pendidik.

Menghadapi permasalahan ini, Terdapat solusi alternatif yang dapat digunakan. Solusi tersebut adalah dengan cara menerapkan pendekatan pembelajaran yang diharapkan dapat mengembangkan kemampuan pemecahan masalah dan kreativitas peserta didik. Pendekatan pembelajaran yang dimaksud yaitu pendekatan berpikir kausalitik.

Pendekatan berpikir kausalitik merupakan pendekatan yang mengarahkan peserta didik untuk berpikir secara luas atau berpikir divergen. Peserta didik tidak lagi berpikir bahwa setiap permasalahan yang 
dihadapi hanya memiliki satu jalan keluar, namun setiap permasalahan yang dihadapi memiliki berbagai jalan keluar. Pendekatan berpikir kausalitik ini sendiri dalam pembelajaran fisika pertama kali dikemukakan oleh Rokhmat et al. (2012).

Menurut Rokhmat (2013), pendekatan berpikir kausalitik dapat mengembangkan kemampuan pemecahan masalah. Pendekatan berpikir kausalitik yang menganut berpikir divergen juga diharapkan dapat mengembangkan kreativitas peserta didik. Namun berdasarkan penelitian yang dilakukan Rokhmat sendiri terhadap calon guru fisika pada tahun 2013, pendekatan berpikir kausalitik masih belum berfungsi secara maksimal. Hal ini disebabkan oleh bentuk dari pendekatan berpikir kausalitik yang masih sangat standar mengakibatkan para peserta didik kesulitan untuk memahaminya. Agar pendekatan berpikir kausalitik dapat diterapkan pada tingkat SMAN dan agar kejadian yang sama tidak terulang kembali, pendekatan berpikir kausalitik harus dipadukan dengan teknik lain yaitu scaffolding. Hal ini sesuai dengan yang disarankan oleh Rokhmat (2013) yaitu agar tahapan selanjutnya berjalan dengan baik dan maksimal, pendekatan berpikir kausalitik perlu dipadukan dengan tahapan (scaffolding). Scaffolding yang diberikan diharapkan dapat membantu para peserta didik dalam memahami tahapan dari pendekatan berpikir kausalitik serta diharapkan mampu mengembangkan proses dari pendekatan berpikir kausalitik peserta didik itu sendiri.

Berdasarkan pendapat Rokhmat (2015), terdapat delapan tipe pola berpikir kausalitik berbantuan tahapan (scaffolding). Delapan tipe pola berpikir kausalitik berbantuan scaffolding ini adalah tipe 1a sampai 4a dan 1 b sampai 4b. Pada pola a, tidak diberikan contoh penjelasan dari permasalahan yang diberikan. Sedangkan pada pola $\mathrm{b}$, diberikan contoh penjelasan dari permasalahan yang diberikan sehingga akan timbul rangsangan untuk berpikir pada peserta didik. Tamami et al. (2017) melakukan penelitian menggunakan pola a tepatnya tipe 2a. Hasil dari penelitian tersebut menunjukan bahwa tipe 2 a terbukti berpengaruh positif terhadap kemampuan pemecahan masalah peserta didik namun tidak berpengaruh terhadap kreativitasnya. Bedasarkan hasil penelitian tersebut, pola $b$ dipilih untuk digunakan dalam penelitian ini. Tipe berpikir kausalitik scaffolding yang digunakan lebih tepatnya adalah tipe $2 b$, yaitu pengembangan berpikir kausalitik dengan bantuan pola utama tabel kausalitas dan sebagian akibat dalam tabel tersebut sudah diberikan serta diberikan bantuan penjelasan dari suatu permasalahan. Kemudian peserta didik diminta menentukan komponen-komponen penyebab dan akibat lainnya dengan jumlah yang sudah diketahui dari suatu fenomena fisika. Selanjutnya peserta didik diminta memberi penjelasan bagaimana penyebab tersebut itu dapat menghasilkan akibat tersebut (Rokhmat, 2015).

Penggunaan tipe $2 b$ bertujuan memunculkan rangsangan pada peserta didik untuk berpikir. Peserta didik diharapkan tidak kesulitan dalam mengerti apa yang harus dikerjakan dengan adanya penjelasan yang diberikan pada pola $2 b$. Modifikasi juga dilakukan pada pola $2 \mathrm{~b}$ yaitu dengan memberikan jumlah dari penyebab pada tabel kausalitas dan memberikan beberapa penyebab pada tabel kausalitas tersebut. Modifikasi ini bertujuan agar peserta didik dapat menentukan penyebab-penyebab lain yang mempengaruhi. Pola yang sama sebelumnya telah digunakan dalam penelitian Helmi et al. (2017). Pada penelitanya, Helmi et al. (2017) mendapatkan pengaruh positif dari pendekatan berpikir kausalitik tipe $2 \mathrm{~b}$ 
modifikasi terhadap kemampuan pemecahan masalah peserta didik.

Penggunaan berpikir kausalitik digunakan pada materi pembelajaran fisika yaitu optik geometri. Sebab kebanyakan dari peserta didik mengalami kesulitan memahami konsep ketika mempelajarai tentang optik geometri. Hal ini didukung dengan pendapat Tamami et al. (2017) yaitu peserta didik memiliki pemahaman yang kurang tentang konsep dari optik geometri.

\section{METODE PENELITIAN}

Penelitian ini dilakukan pada kelas XI MIA SMAN 3 Mataram tahun ajaran 2017/2018 dengan jenis penelitian eksperimen. Desain dari penelitian ini adalah control group design dan cara pengambilan sampel yang digunakan adalah purposive sampling. Sampel yang digunakan pada penelitian ini antara lain XI MIA 8 sebagai kelas eksperimen dan XI MIA 9 sebagai kelas kontol.

Terdapat beberapa variabel yang digunakan dalam penelitian ini. Variabel tersebut yaitu pendekatan berpikir kausalitik scaffolding tipe $2 \mathrm{~b}$ modifikasi sebagai variabel bebas serta kemampuan pemecahan masalah materi optik dan kreativitas sebagai variabel terikat. Kedua variabel terikat tersebut diukur menggunakan instrumen soal yang sama. Instrumen soal tersebut diberikan pada awal pembelajaran sebagai tes awal, serta diberikan pada akhir pembelajaran sebagai tes akhri.

\section{HASIL DAN PEMBAHASAN}

Pengambilan data masing-masing veriabel terikat dilakukan dengan mempertimbakan setiap indikator dari masing masing variabel. Kemampuan pemecahan masalah materi optik peserta didik dinilai menggunakan 6 indikator yaitu understanding, selecting, differentiating, determining, applying, dan identifying dengan penyebutan masing-masing indikator tersebut adalah IPM-1, IPM-2, IPM-3, IPM-4, IPM-5, dan IPM-6. Sedangkan kreativitas peserta didik dinilai menggunakan 4 indikator yaitu fluency, flexibility, originality, dan elaboration dengan penyebutan setiap indikator tersebut adalah IK-1, IK-2, IK-3, dan IK-4.

\section{Kemampuan Pemecahan Masalah (KPM) \\ Data KPM yang telah didapatkan terangkum dalam Tabel 1 berikut.}

Tabel 1. Data KPM Kelas Kontrol dan Eksperimen

\begin{tabular}{|c|c|c|c|c|c|c|c|}
\hline Tes & Kelas & $\begin{array}{c}\text { Jumlah } \\
\text { Peserta } \\
\text { Didik }\end{array}$ & $\begin{array}{l}\text { Nilai } \\
\text { Min. }\end{array}$ & $\begin{array}{l}\text { Nilai } \\
\text { Max. }\end{array}$ & Rata-rata & Varians & Distribusi \\
\hline \multirow{2}{*}{ Awal } & Kontrol & 30 & 6,67 & 30,00 & 17,78 & \multirow{2}{*}{ Homogen } & \multirow[t]{2}{*}{ - } \\
\hline & Eksperimen & 30 & 3,33 & 30,00 & 13,67 & & \\
\hline \multirow{2}{*}{ Akhir } & Kontrol & 30 & 13,33 & 43,33 & 29,56 & & Normal \\
\hline & Eksperimen & 30 & 43,33 & 83,33 & 57,00 & & Normal \\
\hline
\end{tabular}

Tabel 1 memperlihatkan bahwa KPM awal dari kelas kontrol dan eksperimen relatif sama. Hal ini terbukti dengan varian data awal yang homogen. Setelah diberikan perlakuan, rata-rata KPM kedua sampel meningkat. Rata-rata kontrol meningkat sebesar 11,78 sedangkan rata-rata kesperimen meningkat sebesar 43,33.
Peningkatan rata-rata KPM sampel eksperimen yang lebih besar dibandingkan dengan sampel kontrol menandakan bahwa pendekatan berpikir kausalitik scaffolding tipe $2 \mathrm{~b}$ modifikasi dapat meningkatkan KPM peserta didik dengan baik. Hal ini juga didukung dengan hasil uji hipotesis yang menggunakan uji-t. adapun hasil uji-t 
menunjukan bahwa thitung lebih besar daripada $t_{\text {tabel }}$ yaitu 12,621 > 2,004. Hasil ini membuktikan bahwa terdapat pengaruh pendekatan berpikir kausalitik scaffolding tipe $2 \mathrm{~b}$ modifikasi terhadap kemampuan pemecahan masalah materi optik peserta didik.

Data KPM didapatkan dengan cara menilai jawaban peserta didik melalui beberapa indikator. Gambar 1 berikut akan memperlihatkan persentase dari indikator KPM kedua sampel penelitian.

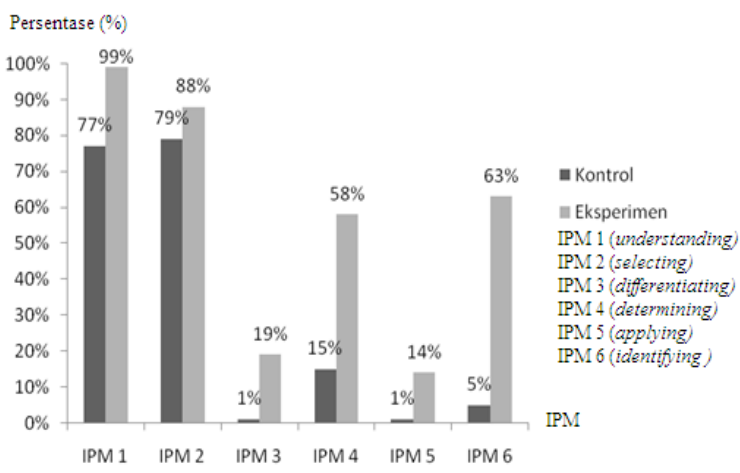

Gambar 1. Persentase Indikator KPM Kedua Sampel

Gambar 1 menunjukan bahwa Persentase IPM tertinggi adalah IPM-1 sebesar 99\% dan IPM-2 sebesar 88\% sedangkan IPM-4 dan IPM-6 bernilai 58\% dan 63\%. Persentase IPM-3 dan IPM-5 adalah sebesar $19 \%$ dan $14 \%$.

Persentase IPM terlihat pada contoh jawaban berikut. Gambar 2 berikut adalah contoh jawaban dari peserta didik saat menjawab instrumen soal nomor 1 .

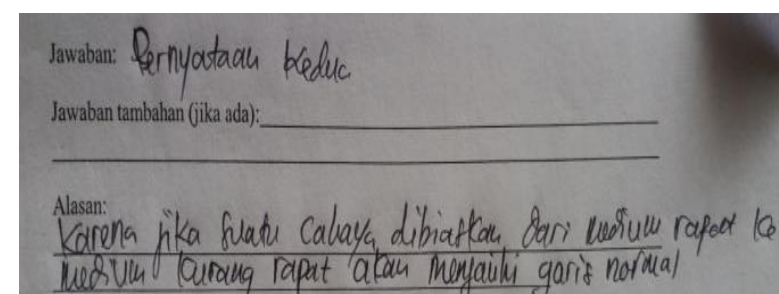

Gambar 2. Contoh Jawaban Peserta Didik 1

Berdasarkan Gambar 2, jawaban peserta didik memperlihatkan bahwa peserta didik mengerti maksud dari soal sehingga peserta didik berhasil mendapatkan skor pada IPM-1. Peserta didik juga berhasil memilih minimal satu jawaban yang mungkin berpeluang terjadi yaitu peryataan kedua sehingga peserta didik berhasil mendapatkan skor pada IPM-2. Peserta didik mencantumkan salah satu teori tentang pembiasan sehigga peserta didik mendapatkan skor pada IPM-4. Peserta didik berhasil medapatkan skor pada IPM-1, IPM2, dan IPM-4 sehigga peserta didik berhasil mendapatkan skor pada IPM-6. Peserta didik tidak membedakan berbagi penyebab menjadi akibat tertentu dan peserta didik tidak menggunakan teori yang dicantumkannya untuk menjelaskan fenomona pada soal. Hal ini yang menyebabkan peserta didik kehilangan skor pada IPM-3, dan IPM-5.

\section{Kreativitas}

Kreativitas dinilai dengan memperhatikan bagaimana cara peserta didik menyajikan jawabanya. Tabel 2 berikut merangkum data kreativitas peserta didik.

Tabel 2. Data Kreativitas Kelas Kontrol dan Eksperimen

\begin{tabular}{cccccccc}
\hline \multirow{2}{*}{ Tes } & Kelas & $\begin{array}{c}\text { Jumlah } \\
\text { Peserta } \\
\text { Didik }\end{array}$ & $\begin{array}{c}\text { Nilai } \\
\text { Min. }\end{array}$ & $\begin{array}{c}\text { Nilai } \\
\text { Max. }\end{array}$ & Rata-rata & Varians & Distribusi \\
\hline \multirow{2}{*}{ Awal } & Kontrol & 30 & 0 & 25 & 13,33 & \multirow{2}{*}{ Homogen } & - \\
\cline { 2 - 6 } & Eksperimen & 30 & 0 & 25 & 9,83 & & Tidak Normal \\
\cline { 1 - 7 } \multirow{2}{*}{ Akhir } & Kontrol & 30 & 0 & 30 & 22,33 & & Tidak Normal \\
\cline { 2 - 6 } & Eksperimen & 30 & 25 & 50 & 35,83 & & \\
\hline
\end{tabular}


Hasil tes awal kedua sampel terbukti homogen. Kelas kontrol mengalami peningkatan sebesar 9 sedangkan kelas eksperimen mengalami penigkatan sebesar 26. Distrubusi data tes akhir kedua sampel terbukti tidak normal.

Hasil dari uji Mann Whiteney menunjukan bahwa nilai Zhitung sebesar 6,69 dan Ztabel sebesar 1,96 tidak memenuhi syarat $-Z_{\text {tabel }}<Z_{\text {hitung }}<Z_{\text {tabel. }}$ Hal ini menunjukan bahwa terdapat pengaruh pendekatan berpikir kausalitik scaffolding tipe $2 b$ modifikasi terhadap kreativitas peserta didik.

Meskipun kreativitas peserta didik mengalami peningkatan yang tidak terlalu pesat, namun pendekatan berpikir kausalitik scaffolding tipe $2 \mathrm{~b}$ modifikasi terbukti berpengaruh terhadap kreativitas peserta didik. Instrumen soal yang digunakan untuk mengambil data kreativitas adalah instrumen yang sama dengan istrumen soal yang digunakan untuk mengambil data KPM. Kreativitas diukur dengan indikator yang berbeda dengan KPM. Gambar 3 berikut merupakan persentase dari masing-masing indikator kreativitas kedua sampel penelitian.

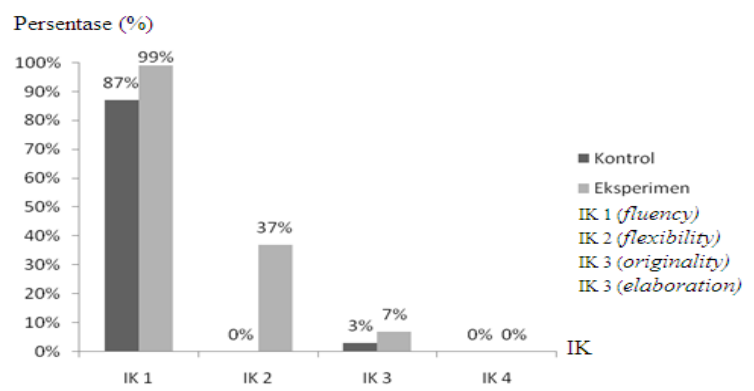

Gambar 3. Persentase Indikator Kreativitas Kedua Sampel

IK-1 memiliki persentase paling tinggi yaitu sebesar 99\% lalu IK-2 dan IK-3 memiliki persentase sebesar $37 \%$ dan $7 \%$. IK-4 memiliki persentase paling rendah yaitu sebesar 0\%. Hal ini menunjukan bahwa tidak ada satupun peserta didik mampu mencapai skor pada IK-4. Gambar 4 berikut merupakan contoh dari jawaban peserta didik pada instrumen soal nomor 2 .

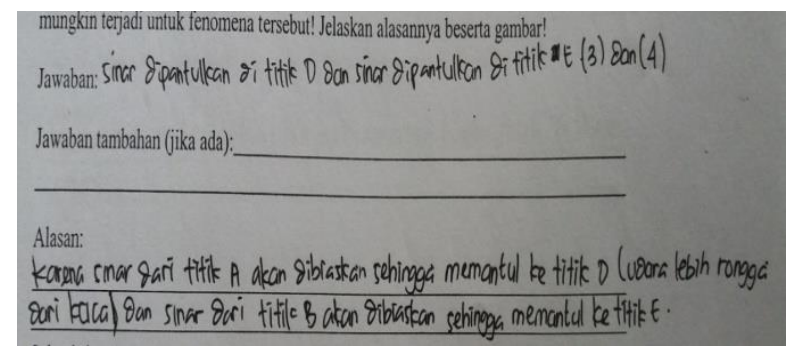

Gambar 4. Contoh Jawaban Peserta Didik 2

Gambar 4 menunjukan bahwa peserta didik berhasil menciptakan jawaban dalam bentuk gagasan serta gagasan yang diciptkan lebih dari satu gagasan. Hal ini menyebabkan peserta didik mendapatkan skor pada IK-1 dan IK-2. Jawaban dari peserta didik mirip dengan jawaban teman-tamanya dan peserta didik tidak menjelaskan secara rinci. Hal inilah yang menyebabkan peserta didik kehilangan skor pada IK-3 dan IK-4.

\section{PENUTUP}

Pada taraf signifikan 5\%, pendekatan berpikir kausalitik scaffolding tipe $2 \mathrm{~b}$ modifikasi berpengaruh terhadap kemampuan pemecahan masalah materi optik peserta didik. pendekatan berpikir kausalitik scaffolding tipe 2b modifikasi juga berpengaruh terhadap kreativitas peserta didik. meski demikian, terdapat berbagai hal yang harus diperbaiki sehingga dapat menjadi masukan bagi penelitian selanjutnya.

Saran yang dapat peneliti berikan adalah menggunakan satu fenomena saja pada setiap LKPD sehigga peserta didik dapat lebih fokus memahami konsep dari fenomena tersebut dan sebaiknya penelitian tentang pendekatan berpikir kausalitik dilakukan sejak jenjang SMP atau bahkan SD sehingga peserta didik dapat terbiasa dengan cara berpikir kausalitik saat penelitian selanjutnya dilakukan pada jenjang yang lebih tinggi. 


\section{REFERENSI}

Deta, U., Suparmi, \& Widha, S. (2013). Pengaruh Metode Inkuiri Terbimbing dan Proyek, Kreativitas, Serta Keterampilan Proses Sains Terhadap Prestasi Belajar Siswa. Jurnal Pendidikan Fisika Indonesia, 9(1), 2834. https://doi.org/10.15294/jpfi.v9i1.2577

Hakim, A., Liliasari, Setiawan, A., \& Saptawati, G. A. (2017). Interactive Multimedia Thermodynamics to Improve Creative Thinking Skill of Physics Prospective Teachers. Jurnal Pendidikan Fisika Indonesia, 13(1), 3340. https://doi.org/10.15294/jpfi.v13i1.8447

Helmi, F., Rokhmat, J., \& 'Ardhuha, J. (2017). Pengaruh Pendekatan Berpikir Kausalitik Ber-Scaffolding Tipe $2 b$ Termodifikasi Berbantuan LKS terhadap Kemampuan Pemecahan Masalah Fluida Dinamis Siswa. Jurnal Pendidikan Fisika dan Teknologi, 3(1) , 68-75. http://dx.doi.org/10.29303/jpft.v3i1.332

Rokhmat, J. (2013). Kemampuan Proses Berpikir Kausalitas dan Berpikir Analitik Mahasiswa Calon Guru Fisika. Jurnal Pengajaran MIPA, 18(1), 18-85. http://dx.doi.org/10.18269/jpmipa.v18i1 .260

Rokhmat, J. (2015). Penerapan Pendekatan Berpikir Kausalitik Ber-scaffolding dalam Meningkatkan Kemampuan Pemecahan Masalah Hukum Newton Tentang Gerak. Prosiding Seminar Nasional Fisika https://www.researchgate.net/publicatio n/324274507_penerapan_pendekatan_b erpikir_kausalitik_berscaffolding_dalam_meningkatkan_kpm _hukum_newton_tentang_gerak

Rokhmat, J., Rusdiana, D., \& Setiawan, A. (2012). Pembelajaran Fisika Berbasis Proses Berpikir Kausalitas Dan Berpikir Analitik (PBK-BA), Suatu Pembiasaan Berpikir Secara Terbuka. Seminar Nasional IX Pendidikan Biologi FKIP UNS. https://jurnal.uns.ac.id/prosbi/article/vie w/7524/6692

Tamami, F., Rokhmat, J., \& Gunada, I. W. (2017). Pengaruh Pendekatan Berpikir Kausalitik Scaffolding Tipe 2a Modifikasi Berbantuan LKS terhadap Kemampuan Pemecahan Masalah Optik Geometri dan Kreativitas Siswa Kelas XI SMAN 1 Mataram. Jurnal Pendidikan Fisika dan Teknologi, 3(1), 76-83. http://dx.doi.org/10.29303/jpft.v3i1.333 